\title{
Sino-Indian Strategic Rivalry in the Indian Ocean Region
}

\author{
Taylan Özgür Kaya \\ Fatih Kılıç
}

\begin{abstract}
This article aims to explicate Sino-Indian strategic rivalry for regional influence in the Indian Ocean Region (IOR). For this purpose, it focuses on actors' actions, which can be interpreted as acts of strategic competition. First of all, it examines Chinese attempts to increase its strategic and economic influence in the region through establishing strong economic and military ties with regional countries including Bangladesh, Myanmar, Sri Lanka, and Pakistan and some connectivity projects like CPEC and BCIM-EC as a part of the Belt and Road Intiative (BRI). Secondly, it investigates Indian counter initiatives as a part of the 'Act East Policy' and 'Neighbourhood First Policy', for strenghtening its political, economic and military ties with the USA and its neighbouring countries such as Iran, Myanmar, Sri Lanka and some connectivity infrastructure projects like the Kaladan Multi Modal Transit Transport Project and the India-Myanmar-Thailand Trilateral Highway. The article argues that although it seems to be a spatial rivalry for gaining and maintaining a total control over the same territory, it is indeed more about a positional rivalry for regional influence, while China seeks to improve its relative position in the IOR, India tries to maintain its relatively advantageous and pre-eminent position in the region.
\end{abstract}

Keywords: China, India, Indian Ocean Region, Energy Security, Seaborne Trade Route, Balancing Strategy.

Öz: Bu makale, Çin ve Hindistan'ın Hint Okyanusu bölgesinde bölgesel bir nüfuz sağlamak için giriştikleri stratejik rekabeti açıklamayı amaçlamaktadır. Bu amaçla, makale her iki aktörün stratejik rekabet olarak yorumlanabilecek faaliyetlerine odaklanmaktadır. Bu çerçevede, ilk olarak Çin'in 'Bir Kuşak Bir Yol İnisiyatifi' kapsamında Bangladeş, Myanmar, Sri Lanka ve Pakistan gibi bölge ülkeleriyle güçlü ekonomik ve askeri bağlar kurma ve Çin-Pakistan Ekonomik Koridoru ve Bangladeş-Çin-Hindistan-Myanmar Ekonomik Koridoru gibi bazı önemli bağlantı projeleri yoluyla bölgedeki stratejik ve ekonomik nüfuzunu artırma girişimleri incelenecektir. İkinci olarak, Hindistan'ın, ABD ve ‘Doğu'ya Yönelim' ve 'Önce Komşular' gibi inisiyatifler çerçevesinde kendine komşu olan İran, Myanmar, Sri Lanka gibi ülkelerle ekonomik ve askeri bağlarını güçlendirme çabaları ve 'Kaladan Multi Modal Transit Ulaşım Projesi' ve 'Hindistan-Myanmar-Tayland Transit Geçiş Yolu' gibi bazı bağlantı projeleri incelenecektir. Sonuç olarak, Hint Okyanusu üzerindeki Çin-Hint rekabeti her ne kadar aynı coğrafi bölge üzerinde mutlak bir kontrol sağlamak üzerine olan 'mekansal bir rekabet' olarak görünse de esasında bölgesel nüfuz elde etmeye yönelik 'pozisyonel bir rekabettir'. Bu çerçevede, bir yanda Çin, Hint Okyanusu bölgesindeki nispi pozisyonunu güçlendirmeye çabalarken öte yandan Hindistan bölgedeki nispeten avantajlı ve üstün pozisyonunu muhafaza etmeye çalışmaktadır.

Anahtar Kelimeler: Çin, Hindistan, Hint Okyanusu Bölgesi, Enerji Güvenliği, Deniz Ticaret Güzergahı, Dengeleme Stratejisi. 


\section{Introduction}

The Indian Ocean stretching from the Persian Gulf and the coast of East Africa to the Malay Archipelago and the shores of Australia together with all its tributary water bodies (Persian Gulf, Red Sea, Malacca Strait, and so on), each of its coastal states, as well as the land-locked states for which the transit to and from the sea is mostly oriented towards the Indian Ocean constitutes the Indian Ocean Region (IOR) (Bouchard \& Crumplin, 2010, p. 33). It is a strategically significant region which was emphasized by a quote ascribed to an American naval officer and strategist Alfred Thayer Mahan stating that "Whoever controls the Indian Ocean dominates Asia. This Ocean is the key to the seven seas in the twenty-first century, the destiny of the world will be decided in these waters" (Yoshihara, 2012, p. 490). The region is rich in natural resources, containing $62 \%$ of the world's proven oil reserves, $35 \%$ of its natural gas, $40 \%$ of its gold, $60 \%$ of its uranium, and $80 \%$ of its diamonds (Erickson et al., 2010, p. 216). Moreover, it is vital to global energy flows and therefore has a major place in the supply side of global energy security (Cordner, 2010, p. 69). It is a key transit route for oil from the Persian Gulf to reach consumers in Europe and Asia (Erickson et al., 2010, p. 216). 17 million barrels of oil a day, constituting $20 \%$ of the world's oil supply and $93 \%$ of oil exported from the Gulf, transits by tanker through the Strait of Hormuz and into the western reaches of the Indian Ocean (Erickson et al., 2010, p. 216). Although a large portion of oil is transported to Europe and the Americas via the Suez Canal and the Cape of Good Hope, the route towards Asia is more important, as Gulf oil meets nearly $75 \%$ of Asia's import needs. Due to this importance, the route is identified as the "new silk road" (Erickson et al., 2010, p. 216).

The region with such rich energy resources and intense trade volume is essential for Asia's two rising powers, China and India, which are increasingly reliant on oil transiting the region. While more than $80 \%$ of China's imported oil and natural gas is carried through the Indian Ocean and the South China Sea (Weimar, 2013, p. 9), nearly $80 \%$ of Indian crude oil requirement is imported by sea, using the international shipping lanes across the Indian Ocean (IN, 2015, p. 24). For this reason, energy resources transited through this trade route are vital for energy security and the key to their energy security is to secure the energy trade route through gaining total control over it. ${ }^{1}$ Since both actors regard the control of this vital

1 Total control over the Indian Ocean is a strategic imperative for both India and China, because it is a largely enclosed ocean, with few entry points and huge distances between. The east-west sea lanes across the ocean, over which much of the world's energy is transited, are highly vulnerable to interdiction. This provides a strategic premium for those powers that are able to control the chokepoints and deny their rivals access to key ports (Brewster, 2015a, p. 49). 
seaborne energy trade route by a foreign and potentially hostile power as a threat to their national interests, they desire to increase their strategic influence and do not want peer competitors in the region which can challenge their strategic clout. Their contest for regional influence in the Indian Ocean has resulted in a strategic competition between them that makes the Indian Ocean a contested space. While China does not officially accept the existence of such a strategic competition and identifies India as a strategic partner in regional and international affairs ${ }^{2}$, India on the other hand in its official discourse, identified China as a rival in the areas of commerce and trade despite the growing economic cooperation between China and India. ${ }^{3}$ Although both actors do not overtly acknowledge the existence of such a strategic competition in the IOR, their initiatives in the region demonstrated the clues of a covert strategic rivalry between China and India. To demonstrate, China has attempted to enhance its naval presence in the Indian Ocean and establish strong economic and military ties with regional countries including Bangladesh, Myanmar, Sri Lanka, and Pakistan through the building and upgrading of port facilities, rail links, pipelines and Signal Intelligence Facilities (SIGINT) etc., which would help to boost its regional influence in the Indian Ocean. On the other hand, India, which has a more advantageous position ${ }^{4}$ when compared to China, aspires to maintain its pre-eminence and prevent China from challenging its predominant status in the region. India, which perceives the Chinese strategic penetration into the Indian Ocean littorals and its naval activities in the region as a profound strategic challenge to its vital political, economic and strategic interests and its preeches denied strategic rivalry between the two countires and existence of a string of pearls strategy by stating that "China never regards India as a threat, but a strategic partner in regional and international affairs". He also added that "China does not intend to dominate or monopolize Asian affairs, and ...China has never thought of containing or balancing India, and there is no such thing as the 'Pearl String Strategy' whatsoever (Jinsong, 2016)."

3 During an interview given to Times magazine on 8 May 2015, as a response to a question on China's increasing assetiveness and influence on the world stage especially in the South Asia region, Indian Prime Minister Narendra Modi identifed China as India's rival in the areas of commerce and trade despite the growing economic cooperation between China and India during the last decades. He also noted that China just like every country has the right to increase its presence, its impact and influence internationally in case it obeys international rules and regulations, and with full respect for human values and acts for the benefit of the global community ("The interview of Prime Minister Narendra Modi with TIME", 2015).

4 The Indian peninsula, which extends south from Eurasia dominates Indian Ocean, gives India a natural centrality to the region. When compared to China, which is geographically in a disadvantageous position in the Indian Ocean due to the necessity to deploy its naval forces to the Indian Ocean through narrow and dangerous chokepoints and then deal with very uncertain logistical support when it arrives, India enjoys a considerable military advantages in the Indian Ocean thanks to short lines of communication to its own bases and resources. Thus, India holds a clear military advantage over China in the Indian Ocean (Brewster, 2015a, p. 50). 
dominant position in the region, has adopted a balancing policy with China. India launched counter initiatives including establishing, broadening and deepening its cooperation and partnership with the USA, Iran, Myanmar and Sri Lanka to contain the growing Chinese influence in the region.

Within this context, this article aims to explicate the Sino-Indian strategic competition for regional influence in the IOR. The first part of the article examines Chinese attempts to expand its influence and ultimately dominate the strategic environment of the IOR. The second part assesses the Indian counter initiatives aiming to protect its maritime backyard and natural sphere of influence in the IOR from Chinese strategic penetration and maintain its pre-eminent position in the region.

\section{Chinese Quest for Boosting Its Regional Influence in the IOR}

The Chinese economy has undergone explosive economic expansion and industrialization since the Chinese leadership implemented an economic policy of gaige kaifang (reform and opening) in December 1978. The rapid energy-intensive industrialization and modernization has increased Chinese energy consumption, in particular that of domestically limited resources such as oil and natural gas. China which had been an oil-exporting country before economic policy of gaige kaifang, became a net importer of oil in 1993 due to a very high oil consumption growth. China's oil consumption has demonstrated a constant increase from $17.5 \%$ in 1995 to $23 \%$ in 2003 and falling again to $17.6 \%$ in 2011, absolute oil consumption grew steadily between 1990 and 2000 - annually by $7.4 \%$ and by $7.3 \%$ between 2001 and 2011. Up from 3.047 million barrels per day (bbl/d) in 1993, China's consumption of crude oil more than tripled to over 9.7 million barrels bbl/d in $2011-11.4 \%$ of global consumption and the second largest after the United States of America (USA) with $20.5 \%$ - with imports amounting to 5.08 million bbl/d (52\% of its total consumption) (Weimar, 2013, p. 7).

Although China has large domestic reserves of natural gas, particularly in its western province Xinjiang, consumption of natural gas exceeded production in 2007. On average, although domestic consumption of natural gas between 2001 and 2011 grew annually by $17.03 \%$, production grew by only 13.1\%. Between 2007 and 2011, the share of imports has increased from a meagre $1.8 \%$ to $21.6 \%$ of its total gas consumption (Weimar, 2013, p. 8).

In terms of energy, China meets $60 \%$ of its oil and natural gas from the Middle East and Central Asia/Caspian reserves. More than $80 \%$ of China's imported oil and natural gas is carried through lengthy and time-consuming sea routes; the 
majority of these routes pass through the highly embattled Indian Ocean and the South China Sea, waters that are subject to the control and increasing influence of China's contenders, primarily India (Weimar, 2013, p. 9).

China meets its energy needs not only from the Middle East through seaborne trade route but also from Central Asia by overland transport routes. Both geographical conditions and other international actors prevent China from accessing the energy resources in Siberia and Central Asia easily. This makes the Indian Ocean, connecting the Middle East with Africa and the South China Sea ${ }^{5}$ vital for Chinese energy security. Thus, as an export-oriented economy with growing energy demand, which can only be met through imports, China's survival and prosperity, is closely bound up with the seaborne trade predominantly passing through the Indian Ocean (Len, 2015, p. 2). China's main strategic imperative in the Indian Ocean is the protection of its sea lines of communication (SLOCs) across the Indian Ocean, particularly the energy transport. The most important of these SLOCs stretch from the Strait of Hormuz at the mouth of the Persian Gulf, around the Indian subcontinent into the Bay of Bengal and through the Straits of Malacca. Other SLOCs stretch across the Indian Ocean from Suez and from southern Africa. China is probably most vulnerable in the Malacca Strait, through which approximately $82 \%$ of China's oil imports pass. According to the Chinese President Hu Jiantao this chokepoint represents China's 'Malacca Dilemma'. China also faces the so-called 'Hormuz Dilemma' in the Persian Gulf, where some $40 \%$ of China's oil imports transit the Strait of Hormuz. Thus, China faces a dilemma across the entire Indian Ocean, where its SLOCs are highly vulnerable to threats from state and non-state actors. Moreover, China's strategic vulnerability is aggravated by the lack of overland transport connections between China's mainland and the Indian Ocean owing to tough geographic barriers created by the mountain ranges, deserts and jungles along the southern edge of the Eurasian continent (Brewster, 2015a, p. 49). Thus, China's geographical disadvantage compels Beijing to look for ways to secure the Indian Ocean trade route for sustaining open trade routes and easy access to energy resources in the Middle East through establishing and maintaining a robust regional naval presence and establishing strong ties with coastal states of the IOR. As part of this strategy, China has been involved in the funding and building of commercial port facilities in South Asian countries at Chittagong in Bangladesh, Hambantota in Sri Lanka, Kyaukpyu in Myanmar and Gwadar in Pakistan and has

$561 \%$ of the total global container traffic and $70 \%$ of traffic in petroleum products are transiting through the Indian Ocean (Venkatshamy, 2013, p. 17). 
intensified political, economic and defence relations with South Asian countries including Bangladesh, Sri Lanka, Nepal, Myanmar and Pakistan.

Since the Bay of Bengal occupies a very significant place in the Chinese Indian Ocean strategy, China has improved its relations with Bangladesh and become the largest supplier of military equipment to Bangladesh in the last decade, especially naval forces. China is also trying hard to improve its commercial interests in the maritime area. It intends to benefit from massive recently discovered oil and gas deposits in the region, using the advantage of geographical proximity of Bangladesh to Myanmar and plans to transport these reserves to the Chinese market via Myanmar pipelines. Stepping up competition with India for regional influence, China have signed 27 deals on cooperation with Bangladesh in a number of sectors, including coastal disaster management and construction, communication technology, investment, maritime cooperation, disaster management and cultural and people-to-people contacts during the Chinese president Xi Jinping's Dhaka visit in October 2016 (Senior Correspondent, 2016).

China and Bangladesh have enhanced their bilateral trade, business, and tourism through developing road links between Kunming and Chittagong via Myanmar and air routes connecting Kunming and Dhaka (Katoch, 2009, p. 32). Chittagong port has an important place in the Chinese project of establishing a network of ports, stretching from its own coastline through Southeast Asia, the Indian Ocean, the east coast of Africa, and through the Mediterranean to Greece, the so-called Silk Road Economic Belt and the 21st Century Maritime Silk Road, or the Belt and Road Initiative $^{6}$ (BRI) (Shepard, 2016). China earmarked $\$ 9$ million for the expansion and modernization of the Chittagong port in 2010 (Shepard, 2016). Although it was designed as a commercial project - building a container port facility, Chinese possible use of the Chittagong port for military and strategic purposes is a major concern for India. In November 2016, Bangladesh received the first submarines from China to boost sea power in the Bay of Bengal and the submarines would be supported by Chinese troops for some time that caused great concern for India (Jha, 2016). 
Sri Lanka, is another significant country for China's South Asia policy. China considers Sri Lanka as a shipping centre in the Indian Ocean and primary partner in the BRI. In fact, Sino-Sri Lankan relations have been growing since the 1990s. Chinese arms sales to Sri Lanka, which began during the civil war in Sri Lanka (1983-2009), have increased dramatically since 2007 with the sale of Jian-7 fighter jets, antiaircraft guns, JY-11 3D air surveillance radars (Chellaney, 2009). In addition to that, China funded the development of a new port and an associated international airport in Hambantota in the southeast of Sri Lanka, costing around $\$ 1$ billion (Chellaney, 2009). On 29 July 2017, Sri Lanka signed a \$1.1 billion deal which sells a $70 \%$ stake of the Hambantota port to China's state-run conglomerate China Merchant Port Holdings. According to many security experts, like Chittagong, Hambantota has a dual use potential which can be used for both commercial and military purposes. Although China plans to use the port as a refuelling and docking station for its navy while patrolling the Indian Ocean and protecting China's supplies of Saudi oil (Katoch, 2009, p. 33), its proximity to the sea lanes that round the southern tips of India is considered by some analysts as proof that it would potentially be used by the Chinese Navy (Brewster, 2014, p. 139).

Nepal is another country occupying a special place in China's South Asia policy and the BRI. Sino-Nepali relations are not completely free of strain. China has great concerns about anti-China activities of 20,000 Tibetan refugees living in Nepal and the US influence on Nepal (Katoch, 2009, pp. 27-28). China is looking for ways to improve its economic and military relations with Nepal in order to alleviate these concerns. China has promised assistance for promoting Nepal's hydro-power projects, and pledged \$2.6 million military assistance for Nepal's security sector (Katoch, 2009, p. 29).

China has built a $700 \mathrm{~km}$ rail link between Lhasa, Tibet with Khasa, Nepal for accelerating the Sino-Nepali economic integration by improving the transport infrastructure in the Himalayan region and reducing Nepal's dependence on India. Another Chinese initiative in Nepal is the railway project that will link Golmud in the Qinghai province to Lhasa in Tibet, which is designed to integrate Tibet with the Chinese economy (Ramachandran, 2008). On 12 May 2017, Nepal and China signed a 'Memorandum of Understanding on the Belt and Road Initiative' in Kathmandu, which makes China and Nepal partners in the BRI.

Myanmar is another strategically salient country for China and the BRI, which can provide China with an overland transportation link to the Indian Ocean. Due to its geographical proximity to the Strait of Malacca, Myanmar enables China to export its goods directly through its own territory. China and Myanmar 
have a close economic, political and arms supply relationship (Brewster, 2015a, p. 55). China and Myanmar have an increasing military cooperation since 1988 (Geng, 2007, p. 3). During the 1990s, China was involved in the development or upgrading of several ports in Myanmar and the construction of a SIGINT facility in the Bay of Bengal. China has begun to build and upgrade road and rail network systems that range from the Yunnan province in the South of China to several ports along the Myanmar coast in the Bay of Bengal. In 1992, Beijing pledged that China would provide great assistance for the modernization of the marine facilities in Myanmar, including the Hianggyi Island and the Coco Islands (Brewster, 2015a, pp. 55-56).

The Myanmar-controlled Coco Islands have a very strategic position for the Chinese Navy. They are only about $30 \mathrm{~km}$ north of the Indian-controlled Andaman Islands. By the year 2050, China, which is planning to achieve world-class blue water naval status, is expecting that Myanmar-controlled islands will provide China with a direct access to the Pacific and the Indian Oceans. By not passing through the Strait of Malacca to reach the Bay of Bengal, the Chinese Navy would shorten the distance by $3000 \mathrm{~km}$, reducing the journey by five to six days (Shee, 2002, p. 36). China established a modern reconnaissance and electronic intelligence system on the Coco Islands in 2003 to monitor India's military movements, including missile testing in the Indian Ocean (Geng, 2007, p. 3). The discovery of oil and gas fields in Myanmar is another factor that increases its significance for China. Production sharing agreements were signed between the Chinese National Offshore Oil Company and the Myanmar Oil and Gas Enterprise between October 2004 and January 2005 (Van Gelder \& Law, 2009).

In order to mitigate its strategic vulnerability due to its high degree of dependence on the Strait of Malacca for the importing of hydrocarbons from the Middle East (Kaplan, 2013), the so-called Malacca Dilemma, it has invested heavily in Myanmar's oil and natural gas pipelines for the purpose of forming an alternative energy transit route. The oil and gas pipelines ${ }^{7}$ between the new deep-water port of Kyaukpu in Myanmar and China's southern Yunnan province for transporting gas from Myanmar's offshore gas fields and oil shipped from the Middle East (Brewster, 2014, p. 138), and the construction of a railway between Kunming and Lashio are other Chinese attempts in Myanmar to enhance bilateral economic relations (Shee, 2002, p. 36). 
Pakistan is another strategically salient country, which can provide China with an alternative overland transportation link to the Indian Ocean, like Myanmar. Pakistan has been seen as an all-weather strategic cooperative partner by China (Weidong, 2016). China considers Pakistan an important bypass line which enables it to access to the Indian Ocean directly, instead of using long seaborne trade routes stretching from its own coast to the Middle East (Khurana, 2008, p. 9). For this reason, it initiated some infrastructure projects in Pakistan in order to accelerate the export of Chinese goods to world markets. A large part of China's trade is carried out through a very long distance passing through the Strait of Hormuz-Indian Ocean-South China Sea transportation line which results in a great loss of time and has serious security risks. For this reason, China aims to reach the Arabian Sea by passing through Kashmir and Pakistan from its mainland instead of using this long and time-consuming route.

The most striking development in the Sino-Pakistani cooperation is the China-Pakistan Economic Corridor (CPEC) between Gwadar and Kashi in the Chinese northwest province of Xinjiang, which consists of an improved road and rail links and a proposed oil pipeline ${ }^{8}$ and road and rail link from Gwadar to Kashi. CPEC is one of the most important projects of the 'single-generation, one-way' project aiming to improve transport connectivity between China's western Xinjian province and the Arabian Sea through Pakistan (Brewster, 2015a, p. 53). CPEC, which is the major and pilot project of the BRI, is a part of one of the three blue economic passages (China-Indian Ocean-Africa- Mediterranean Sea Blue Economic Passage) China is planning to build as a part of BRI. It aims to deepen ocean cooperation by fostering closer ties with countries along the Road. Construction of a deep-sea port in Gwadar has the most strategic significance for China, because it is very close to a major oil supply route - about $70 \mathrm{~km}$ from the Iranian border and $400 \mathrm{~km}$ east of the Strait of Hormuz (Pant, 2012, p. 366). China and Pakistan have agreed on the establishment of a "single corridor, multiple passages" aiming to establish an effective link to Gwadar Port to ensure that all regions in Pakistan benefit from economic and social development ("10 Fundamentals of CPEC", n.d.). In this way, they aim to contribute to the development of economically underdeveloped regions of Pakistan. The trans-Myanmar and trans-Pakistan projects are part of Beijing's 'bridgehead strategy' which aims to turn Chinese provinces of Yunnan and Xinjiang into gateways for economic engagement with the Indian Ocean (Brewster, 2015a, p. 53). India has deep concerns about the CPEC, because a part of the pro- 
ject passes through Gilgit-Baltistan, which is part of Pakistan-occupied-Kashmir, a territory that India considers as its own. India refused to participate in the Belt and Road Forum for International Cooperation held in Beijing on 14 and 16 May 2017 due to its concerns on sovereignty and territorial integrity related with the issue of Kashmir ("Official Spokesperson's response to a query on participation of India in OBOR/BRI Forum", 2017). The Bangladesh, China, India and Myanmar Economic Corridor (BCIM-EC) project is, like CPEC, a significant component of the China-Indian Ocean-Africa- Mediterranean Sea Blue Economic Passage under the framework of BRI. It involves building a road and manufacturing corridor from Kunming to Calcutta, via Myanmar, India's northeast states and Bangladesh, at a claimed cost of $\$ 20$ billion (Brewster, 2015a, p. 53).

\section{India's Counter-initiatives to Forestall a Sino-Centric IOR}

According to Indian strategic thinking, the Indian Ocean is regarded as the Indian maritime backyard and its natural sphere of influence. It has also been seen as both natural and desirable that India functions as, ultimately, the leader and the predominant influence in the IOR - the world's only region and ocean named after a single state (Brewster, 2015b, p. 231). There is a well-established belief in the Indian strategic community that the Indian Ocean is 'India's Ocean' (Scott, 2006, p. 99). Since its independence Indian leaders identify with establishing a total control over its namesake ocean as India's manifest destiny. For instance, India's first Prime Minister Jawaharlal Nehru stated that 'whatever power controls the Indian Ocean has, in the first instance, India's seaborne trade at her mercy and, in the second, India's very independence itself', and the first Deputy Prime Minister of India Sardar Patel emphasized that 'the geographical position and features of India make it inevitable for India to have a strong navy to guard its long coastline and to keep a constant vigil on the vast expanse of the sea that surrounds India' (Holslag, 2009 , p. 824). It was also stated in the Indian Maritime Strategy of 2007, India can only "attain its manifest destiny" if it is able to "provide insulation from external interference" in the Indian Ocean and become the pre-eminent power in the region (Wojczewski, 2016, p. 39).

In addition to its geostrategic significance, the Indian Ocean is vital for India's energy security. Just like China, India's energy consumption has gradually increased with its fast growing economy. Since its own resources are inadequate to cater for its increasing energy consumption, it became an energy importing country and $70 \%$ dependent on oil imports to meet its energy requirements and it is expected to reach $85 \%$ by 2020 (Berlin, 2011, p. 7). Just like China, India is heavily depen- 
dent on seaborne energy trade which is carried out through the international shipping lanes across the Indian Ocean. About $80 \%$ of Indian crude oil requirement is imported by sea, using the international shipping lanes across the Indian Ocean (IN, 2015, p. 24).

India, which regards itself as a predominant power in the Indian Ocean, is uncomfortable with China's growing influence over the region and its close partnership with littorals of the Indian Ocean through BRI. Many Indian strategic analysts claimed that China's regional relations are directed against India: either as a plan of maritime 'encirclement' of India or to keep India strategically off balance in the region (Brewster, 2014, p. 139). They believe that the expansion of China's strategic depth in India's backyard (Pant, 2012, p. 365), is a great challenge to India's predominant position in the Indian Ocean, and the ports China has been building and upgrading in the IOR would be used for not purely economic and commercial purposes but also military and strategic purposes. In order to mitigate this challenge, New Delhi decided to implement a balancing strategy to neutralize Chinese growing influence over the region and maintain and consolidate Indian pre-eminence in the region. Since growing Chinese presence in the Indian Ocean is a common concern for both India and major powers such as the USA and some littoral countries in the Indian Ocean, India has established, broadened and deepened its cooperation and partnership with the USA, Iran, Myanmar, Sri Lanka, Thailand, Malaysia, Indonesia and Singapore as part of its balancing strategy against China. In order to balance Chinese growing strategic and economic influence with the BRI and to expand India's sphere of influence, Indian Prime Minister Narenda Modi adopted two complementary foreign policy strategies: the 'Act East Policy' and the 'Neighbourhood First Policy'.

The USA is the prominent strategic partner of India which shares a common concern about Chinese growing presence in the IOR. The Indo-US defense partnership is based on common principles and shared national interest and strategic objectives, such as fighting terrorism, preventing the proliferation of weapons of mass destruction, and maintaining peace, security and stability in the IOR. During the last two decades, comprehensive defense agreements have been signed between the two countries which allow them to cooperate in many areas. The most important one is the 'Defense Framework Agreement' of 1995, which covered a period of 10 years and was extended again in 2005 as the 'New Framework for the US-India Defence Relationship'. It provides a general framework for all defence cooperation initiatives between the two actors, including joint exercises, cooperation in multilateral operations, missile defense, and an intensification of the strategic dialogue between the ministries of defence (Wojczewski, 2016, p. 42). They also agreed to 
extend the US defense technology transfer to India and the joint development and production of defense goods, which enables India to have access to sensitive, cutting-edge military technology and to a certain extent balances China's quantitative superiority (Wojczewski, 2016, p. 42). Furthermore, the use and development of common weapon systems increases the interoperability between the armed forces of both countries (Wojczewski, 2016, p. 42). Within the framework of this agreement, the two countries have carried out joint military exercises regularly, including joint naval, air force, and army exercises as well as joint maritime patrols in the Strait of Malacca, which are implicitly directed against China in the sense that they should prevent China from taking any hostile actions by demonstrating potential alignment options (Wojczewski, 2016, p. 42).

India, which has deep concerns about the security and strategic implications of the Chinese efforts to establish maritime infrastructure in the IOR has embarked on advancing its maritime cooperation with the Indian Ocean littoral states that share the same concerns with India including Thailand, Malaysia, Indonesia and Singapore. As a part of this cooperation, India has formed several cooperative security mechanisms with Indian Ocean littorals including MILAN naval exercises (India, Australia, Bangladesh, Cambodia, Indonesia, Kenya, Malaysia, Maldives, Mauritius, Myanmar, New Zealand, the Philippines, Seychelles, Singapore, Sri Lanka, Tanzania and Thailand), MALABAR (India, USA, Japan), IBSAMAR series of exercises (India, Brazil, South Africa), JIMEX (India and Japan), SIMBEX Joint exercises (India and Singapore), SLINEX-II (India and Sri Lanka), PASSEX (India and USA), CORPAT (India-Indonesia Coordinated Patrols, Indo-Thai Coordinated Patrols) (Upadhyaya, 2014, pp. 183-185).

Iran is one of the key countries for Indian balancing policy. For several reasons, maintaining good relations with Iran is an imperative for India's energy security and commercial interests. The first reason is that India's uneasy relations with China and Pakistan makes Iran the only access to the untapped markets of Afghanistan and Central Asia for Indian goods, as well as being its major option for tapping the vast energy and other mineral resources of the region (Bansal, 2012, p. 847). Due to its geopolitical imperatives, in order to have a role in Afghanistan or Central Asia, it is almost inevitable for India to maintain good relations with Iran. Moreover, Iran provides India with the shortest access to the vast energy resources of the Caspian basin and the Caucasus region. The growing Indian economy not only requires the vast untapped markets of the central Eurasian landmass, but also needs newer sources of energy supplies (Bansal, 2012, p. 848). For this reason, during the Premiership of Narenda Modi, India has tried to improve its relations with Iran 
and accelerated several infrastructure development projects, which have already started before. First of all, India has sponsored the development and restructuring of the Iranian port of Chabadar, located on the Gulf of Oman, between Gwadar and the Strait of Hormuz. On 23 May 2016, India and Iran signed a commercial contract for the development and operations of Chabahar Port during Modi's visit to Iran. India has pledged to invest $\$ 500$ million for the development of the Chabahar port and related infrastructure as a part of this agreement ("Prime Minister's statement to the media during his visit to Iran", 2016). India's participation in the development of Chabahar Port is expected to provide India an alternative and reliable access route into Afghanistan utilizing India's earlier investment in the Zaranj-Delaram road built in Afghanistan, and also a reliable and more direct sea-road access route into the Central Asian Region. The Chabahar Port's location on the Arabian Sea means that it would be able to skirt any challenges posed by developments in the Persian Gulf and the Strait of Hormuz ("Question No. 432", 2016). Moreover, on the same day as the India-Iran agreement on the Chabadar Port, India, Iran and Afghanistan signed a Trilateral Agreement on the Establishment of an International Transport and Transit Corridor, which will provide India much-needed access to Afghanistan and Central Asia in the absence of transit rights through Pakistan (Chaudhury, 2016). Another grand project passing through Iran and providing India with an alternative and reliable access to Central Asia and even Russia is the International North-South Transportation Corridor (INSTC). INSTC runs from the Chabahar port to Afghanistan and the Central Asian republics and to Russia via the Caspian Sea. It is a $7,200 \mathrm{~km}$ road, rail and sea route that connects India with Iran and Russia for the purpose of promoting transportation cooperation among the member states. It connects the Indian Ocean and Persian Gulf to the Caspian Sea via Iran, and is then connected to St. Petersburg and Northern Europe via Russia (Devonshire-Ellis, 2017). All these Indian efforts in the development of the Chabadar Port and INSTC can be seen as an attempt to create a viable alternative to Chinese CPEC in the framework of BRI.

Myanmar is one of the salient countries for the Indian balancing policy against China. Due to its geopolitical position, Myanmar has been vital for Indian security interests in the Bay of Bengal and the Andaman and Nicobar Islands. It also constitutes a landbridge between South Asia and Southeast Asia and a crucial buffer-zone separating India's turbulent Northeast and China's southern provinces. In case China is able to penetrate completely into Myanmar and make it a Chinese "client state," China will be able to complete India's encirclement or containment (Rehman, 2009, p. 124). In addition to the 'China factor', its strategic location on the East Asia transit line and its potential partner role for dealing with problems 
in the India's north-east neighbourhood and its vast natural resources make Myanmar a vital country for Indian foreign policy and a salient country for the achievement of its national goal of becoming the leading country in the region (GoIMEA, 2014). After the launching of the 'Look East Policy' in the early 1990s, India began to improve its relations with Myanmar in order to prevent it from making a hotbed of Chinese interference in the region and also from becoming a safe haven for the guerrilla movements which plague India's north-eastern borders. During the 2000s, India has worked hard to wrest it from China's sphere of influence by engaging the military junta in Myanmar, supplying it with military aid, sending engineers to help repair its infrastructure and providing it with soft loans at very advantageous interest rates for the construction of Myanmar's multiple infrastructure projects, including Kaladan project and Kalay-Kalaywa-Kyiga-Tamu Road in the Sagaing Division of Myanmar. After successive high-level bilateral visits in the 2000s, the two countries have signed several agreements and memorandums of understanding and Myanmar has promised not to allow anti-Indian activities on its land. Both countries' armed forces have frequently coordinated their efforts in anti-insurgency operations on both sides of the border (Rehman, 2009, p. 134).

During Narenda Modi's premiership, India-Myanmar relations have developed rapidly and India accelerated its infrastructure commitments in Myanmar as a part of its 'Act East Policy' and 'Neighbourhood First Policy'. India has been developing the Kaladan Multi Modal Transit Transport Project in Myanmar, which includes a waterways component of $158 \mathrm{~km}$ on the Kaladan river from Sittwe to Paletwa in Myanmar and a road component of $109 \mathrm{~km}$ from Paletwa to Zorinpui on the India-Myanmar border in Mizoram State. The waterways component, which comprises Sittwe Port, Inland Water Transport (IWT) terminals, backup facilities and a navigational channel, has been completed. However, the road component of the project is still under construction ("Question No. 6280", 2017). The project, which will connect Sittwe Port in Myanmar to the India-Myanmar border, is expected to contribute to the economic development of the North-Eastern States of India, by opening up the sea route for products. It will also provide a strategic link to the North-East, thereby reducing pressure on the Siliguri Corridor. It is also expected that in the absence of an alternate route, the development of this project not only serves the economic, commercial and strategic interests of India, but also contributes to the development of Myanmar, and its economic integration with India ("Implementation of the Kaladan Multi Modal Transit Transport Project in Myanmar", 2015). Another grand project which is expected to increase the economic connectivity between India and Myanmar is the India-Myanmar-Thailand Trilateral Highway, which, when completed in 2020, will connect Moreh in India's 
Manipur state to Mae Sot in Thailand via Tamu in Myanmar. It is expected that this highway will give easy access to the Northeastern states to the sea (via Myanmar) and thereby helping improve connectivity between India's remote Northeastern part and Southeast Asia (Borah, 2017). Although India's infrastructure initiatives seem to be based on economic and commercial reasons, in essence they have been part of the Indian balancing strategy against Chinese increasing infrastructure building activities in Myanmar as a part of BRI, which would increase Chinese influence in Myanmar.

Sri Lanka, with its geographical proximity and common economic, cultural and historical ties with India and its key role in Chinese BRI, is another significant country for the Indian balancing policy. According to Indian analysts, Chinese initiatives in Sri Lanka are efforts for containing India strategically. These initiatives prompted India to establish close relations with Sri Lanka. India has supplied economic aid to Sri Lanka for disaster relief in the aftermath of the 2004 tsunami and the reconstruction of the country. This assistance has made a significant contribution to the improvement of bilateral relations. Moreover, India signed a Foreign Trade Agreement (FTA) and Comprehensive Economic Partnership Agreement (CEPA) with Sri Lanka to consolidate the Sri Lankan economy and to increase bilateral trade (Berlin, 2006). Defence cooperation, intelligence sharing, warship modification and the provision of defence equipment are other areas of bilateral cooperation. Both countries have also carried out joint military exercises every year such as the India-Sri Lanka Joint Military Exercise ‘Mitra Shakti’ since 2013 (GKT, 2016).

\section{Conclusion}

Although Sino-Indian rivalry in the IOR seems to be a spatial rivalry for gaining and maintaining control over the same territory, it is however more related to a positional rivalry for regional influence, while China seeks to improve its relative position in the IOR, India tries to defend its relatively advantageous position and pre-eminence in the region. ${ }^{9}$ Despite the fact that the existence of a Sino-Indian strategic rivalry in the IOR has not been officially acknowledged by both parties, their actions in the region speak louder than their words. Although China identifies India as a potential partner within the framework of the BRI, some of the connectivity infrastructure projects within the framework of the BRI ignores Indian national interets and sensitivies like the CPEC, which passes through a contested 
territory between India and Pakistan. In addition, Chinese proactive diplomacy towards the countries in the IOR is a clear indication of its bid for expanding its influence and ultimately dominating the strategic environment of the IOR. Other contender, India, which feels uncomfortable with Chinese growing strategic and economic influence in its immediate neighbourhood, launched alternative initiatives during the premiership of Narenda Modi, such as 'Act East Policy' and 'Neighbourhood First Policy'. Both strategies aim to balance Chinese growing strategic and economic influence and to consolidate Indian strategic and economic weight in the IOR. As a part of these policies, Modi has tried to strenghten political, economic and military ties with neighbouring countries and also launched some connectivity infrastructure projects like the Kaladan Multi Modal Transit Transport Project and the India-Myanmar-Thailand Trilateral Highway. To conclude, despite Chinese rhetoric of a Sino-Indian partnership, Indian strong criticism about the BRI and its alternative regional initiatives demonstrate that the current Sino-Indian positional rivalry in the IOR is likely to intensify in the coming years.

\section{References}

10 Fundamentals of CPEC. (n.d.). Retrieved November 14, 2016, from China-Pakistan Economic Corridor website, http://www.cpecinfo.com/10-questions-on-cpec.

Bansal, A. (2012). Iran: Its Strategic Importance. Strategic Analysis, 36(6), 848-858.

Berlin, D. (2011). The Rise of India and the Indian Ocean. Journal of the Indian Ocean Region, 7(1), 1-31.

Berlin, D.L. (2006). India in the Indian Ocean. Naval War College Review, 59(2), 58-89.

Borah, R. (2017, August 24). India-Myanmar-Thailand Trilateral Highway: A Promise to Transform the Region's Economic Landscape. Japan Forward. Retrieved October 07, 2017, from https://japan-forward.com/india-myanmar-thailand-trilateral-highway-a-promise-to-transform-the-regions-economic-landscape/.

Bouchard, C. \& Crumplin, W. (2010). Neglected No Longer: The Indian Ocean at the Forefront of World Geopolitics and Global Geostrategy. Journal of the Indian Ocean Region, (6)1, 26-51.

Brewster, D. (2014). Beyond the 'String of Pearls': Is There Really a Sino-Indian Security Dilemma in the Indian Ocean?. Journal of the Indian Ocean Region, 10(2), 133-149.

Brewster, D. (2015a). An Indian Ocean Dilemma: Sino-Indian Rivalry and China's Strategic Vulnerability in the Indian Ocean. Journal of the Indian Ocean Region, 11(1), 48-59.

Brewster, D. (2015b). Indian Strategic Thinking about the Indian Ocean: Striving Towards Strategic Leadership. India Review, 14(2), 221-237.

Chaudhury, D.R. (2016, April 18). India, Afghanistan and Iran Finalise Chabahar Agreement. The Economic Times. Retrieved October 05, 2017, from https://economictimes.indiatimes.com/news/economy/foreign-trade/india-afghanistan-and-iran-finalise-chabahar-agreement/articleshow/51867141.cms.

Chellaney, B. (2009, March 4). China Fuels Sri Lankan War. The Japan Times. Retrieved October 19, 2016, from http://www.japantimes.co.jp/opinion/2009/03/04/commentary/china-fuels-sri-lankan-war/.

Cordner, L. (2010). Rethinking Maritime Security in the Indian Ocean Region. Journal of the Indian Ocean Region, 6(1), 67-85. 
Devonshire-Ellis, C. (2017, May 22). Russia Connecting With India via International North-South Transport Corridor. Russia Briefing. Retrieved October 05, 2017 from https://www.russia-briefing.com/news/russia-connecting-india-via-international-north-south-transport-corridor.html/.

Erickson, A. S., Walter III, L. C. \& Mikolay, J. D. (2010). Diego Garcia and the United States' Emerging Indian Ocean Strategy. Asian Security, 6(3), 214-237.

General Knowledge Today (GKT). (2016, October 26). India-Sri Lanka Joint Military Exercise Mitra Shakti 2016 Begins. Retrieved December 12, 2016, from http://currentaffairs.gktoday.in/india-sri-lanka-joint-military-exercise-mitra-shakti-2016-begins-10201636702.html.

Geng, L. (2007). Sino-Myanmar Relations: Analysis and Prospects. Culture Mandala: The Bulletin of the Centre for East-West Cultural and Economic Studies, 7(2), 1-15.

Government of India Ministry of External Affairs (GoIMEA). (2014). India-Myanmar Relations. Retrieved October 19, 2016, from http://www.mea.gov.in/Portal/ForeignRelation/India-Myanmar_Relations.pdf.

Holslag, J. (2009). The Persistent Military Security Dilemma between China and India. Journal of Strategic Studies, 32(6), 811-840.

Implementation of the Kaladan Multi Modal Transit Transport Project in Myanmar at the Revised Cost Estimate of Rs 2904.04 Crore. (2015, October 14). Retrieved October 07, 2017, from Press Information Bureau of the Government of India website, http://pib.nic.in/newsite/PrintRelease.aspx?relid=128699.

Indian Navy (IN). (2015). Ensuring Secure Seas: Indian Maritime Security Strategy. Naval Strategic Publication. Retrieved June 22, 2017, from https://www.indiannavy.nic.in/sites/default/files/Indian_Maritime_Security_Strategy_Document_25Jan16.pdf.

Jha, S. (2016, December 30). The Bay of Bengal Naval Arms Race. The Diplomat. Retrieved March 7, 2017, from http://thediplomat.com/2016/12/the-bay-of-bengal-naval-arms-race/.

Jinsong, L. (2016, July 22). China's Security and Diplomatic Doctrine In a Globalized Era. Remarks by Mr. Liu Jinsong, Charge d' Affaires of the Embassy of P. R. China in India. Retrieved October 03, 2017, from http://www. fmprc.gov.cn/mfa_eng/wjb_663304/zwjg_665342/zwbd_665378/t1383538.shtml.

Kaplan, R.D. (2013, February 13). China's String of Pearls?. Stratfor. Retrieved June 30, 2017, from https://worldview.stratfor.com/weekly/chinas-string-pearls.

Katoch, D. (2009, Winter). Is China Encircling India?. CLAWS Journal, 27-38.

Khurana, G.S. (2008). China's 'String of Pearls' in the Indian Ocean and its Security Implications. Strategic Analysis, 32(1), 1-39.

Lei, H. (2017, May 01). The Belt and Road Initiative and Its Global Significance. Speech by Consul General Hong Lei at 2017 Silk Road Conference in Chicago. Retrieved October 05, 2017, from http://www.chinaconsulatechicago. org/eng/lgxx/zlsjh/t1458005.htm.

Len, C. (2015). China's 21st Century Maritime Silk Road Initiative, Energy Security and SLOC Access. Maritime Affairs, 11(1), 1-18.

Official Spokesperson's response to a query on participation of India in OBOR/BRI Forum. (2017, May 13). Retrieved October 10, 2017, from the Ministry of External Affairs of India website, http://www.mea.gov.in/ media-briefings.htm?dtl/28463/official+spokespersons+response+to+a+query+on+participation+of+india+in+oborbri+forum.

Pant, H. V. (2012). China Shakes Up the Maritime Balance in the Indian Ocean. Strategic Analysis, 36(3), 364-368.

Prime Minister's statement to the media during his visit to Iran. (2016, May 23). Retrieved October 04, 2017, from the Prime Ministry of India website, http://www.pmindia.gov.in/en/news_updates/media-statement-by-prime-minister-during-his-visit-to-iran/?comment=disable.

Question No.432 India-Iran Agreement on Chabahar Port. (2016, July 21). Retrieved October 04, 2017, from the Ministry of External Affairs of India website, http://www.mea.gov.in/rajya-sabha.htm?dtl/27098/question+no432+indiairan+agreement+on+chabahar+port. 


\section{The Journal of Humanity and Society}

Question No.6280 Kaladan Multi-Modal Transit Transport. (2017, April 12). Retrieved October 07, 2017, from the Ministry of External Affairs of India website, http://mea.gov.in/lok-sabha.htm?dtl/28382/QUESTION_ NO6280_KALADAN_MULTIMODAL_TRANSIT_TRANSPORT.

Ramachandran, S. (2008, May 15). Nepal to get China Rail Link. Asia Times Online. Retrieved December 4, 2016, from http://www.atimes.com/ atimes /So uth_Asia/JE15Df01.html.

Rehman, I. (2009). Keeping the Dragon at Bay: India's Counter-Containment of China in Asia. Asian Security, 5(2), 114-143.

Scott, D. (2006). India's “Grand Strategy” for the Indian Ocean: Mahanian Visions. Asia-Pacific Review, 13(2), $97-129$.

Senior Correspondent (2016, October 14). Bangladesh, China sign 27 deals as President Xi visits Dhaka. bdnews24. Retrieved November 9, 2016, from http://bdnews24.com/bangladesh/2016/10/14/bangladesh-china-sign-27-deals-as-president-xi-visits-dhaka.

Shee, P. K. (2002). The Political Economy of China-Myanmar Relations: Strategic and Economic Dimensions. Ritsumeikan Annual Review of International Studies, 1, 33-53.

Shepard, W. (2016, June 7). Bangladesh's Deep Sea Port Problem. The Diplomat. Retrieved November 12, 2016, from http://thediplomat.com/2016/06/bangladeshs-deep-sea-port-problem/.

The interview of Prime Minister Narendra Modi with TIME. (2015, May 8). Retrieved October 04, 2017, from the Prime Ministry of India website, http://www.pmindia.gov.in/en/news_updates/the-interview-of-pm-narendra-modi-with-time/?comment=disable.

Thompson, W.R. (1995). Principal Rivalries. The Journal of Conflict Resolution, 39(2), 195-223.

Upadhyaya, S. (2014). Maritime Security Cooperation in the Indian Ocean Region: The Role of the Indian Navy. Australian Journal of Maritime \& Ocean Affairs, 6(4), 173-190.

Van Gelder, J.W. \& Law, H. (2009). Financing of Oil Companies in Burma. A research paper prepared for Arakan Oil Watch. Retrieved January 11, 2017, from https://www.banktrack.org/download/financing_of_oil_companies_in_burma.

Venkatshamy, K. (2013). The Indian Ocean Region in India's Strategic Futures: Looking Out to 2030. Journal of the Indian Ocean Region, 9(1), 17-41.

Weidong, S. (2016, September 27). Remarks by Chinese Ambassador Sun Weidong at the Reception Celebrating the 67th Anniversary of the Founding of the People's Republic of China. Retrieved October 07, 2017, from http:// www.fmprc.gov.cn/mfa_eng/wjb_663304/zwjg_665342/zwbd_665378/t1402338.shtml.

Weimar, N.D. (2013). Sino-Indian Power Preponderance in Maritime Asia: a (re-)source of Conflict in the Indian Ocean and South China Sea. Global Change, Peace \& Security, 25(1), 5-26.

Wojczewski, T. (2016). China's Rise as a Strategic Challenge and Opportunity: India's China Discourse and Strategy. India Review, 15(1), 22-60.

Yoshihara, T. (2012). Chinese Views of India in the Indian Ocean: A Geopolitical Perspective. Strategic Analysis, $36(3), 489-500$ 